\title{
INFLUENCE OF SERUM PROTEIN, SERUM ALBUMIN CONCENTRATIONS AND DOSE ON MIDAZOLAM ANAESTHESIA INDUCTION TIMES
}

\author{
J.G. Reves, Philippa Newfield and Lloyd R. Smith
}

\begin{abstract}
Individual variation occurs in time to induction of andesthesia with intravenous drugs. Less free drug is available to cross the blood-brain barrier when the drug is highly protein bound. Since this may prolong time to sleep, we correlated the induction time, serum albumin and total protein concentrations, and doses of midazolam, which is a highly protein bound intravenous anaesthetic. There is a poor correlation $(r=0.062)$ between induction time and serum protein, a weak $(r=0.524)$ but statistically significant $(p=0.026)$ correlation between induction time and serum albumin, and a highly significant $(p=0.003)$ negative correlation ( $r$ $=-0.579$ ) between drug dose and induction time. The administration of the appropriate dose of midazolam for induction, therefore, appears to affect induction time more significantly than does the serum albumin concentration.
\end{abstract}

Key Words: Anaesthetics, Intravenous, midazolam; Protein Binding, midazolam; INDUCTION TIME, midazolam.

Midazolam is a water soluble benzodiazepine drug used for intravenous anaesthesia. ${ }^{1-4}$ Dundee reports considerable individual variation in anaesthetic induction time with midazolam which he suggests may be related to the high degree (95 per cent) of protein binding. ${ }^{5}$ The purpose of this report is to examine previously reported data ${ }^{2}$ to determine whether an association exists between the patients' plasma protein concentration and individual induction time with midazolam.

\section{METHODS}

Thirty patients of ASA physical status 1 or 2 scheduled for elective surgical procedures were selected for study. The patients were not premedicated and were divided into three groups of ten patients each according to drug dosage. Group 1 received $0.1 \mathrm{mg} \cdot \mathrm{kg}^{-1}$, Group 2 received $0.15 \mathrm{mg} \cdot \mathrm{kg}^{-1}$, and Group 3 received 0.20 $\mathrm{mg} \cdot \mathrm{kg}^{-1}$ of midazolam maleate over 15 seconds while the patients breathed room air. Induction

J.G. Reves, M.D., Professor, Department of Anaesthesiology; Lloyd R. Smith, M.S., Data Manager, Clinical Cardiology Computer Center, University of Alabama, Birmingham, Alabama; Philippa Newfield, M.D., Assistant Professor. Department of Anaesthesiology, University of California, San Francisco.

Address for correspondence: J.G. Reves, M.D., Department of Anaesthesiology, School of Medicine, University of Alabama, Birmingham, Alabama 35294 U.S.A. of anaesthesia was defined as complete when there was loss of lid reflex and failure to respond to oral commands. The time for induction was defined as the time from the end of injection until criteria for complete induction were met. The patient's total protein and serum albumin concentrations were measured within 48 hours of induction of anaesthesia.

The association of induction time with protein concentrations and drug dosage was analyzed by the following statistical methods. Stepwise logistic regression ${ }^{6}$ was used to determine which variable - dose, albumin concentration, protein concentration - most affected whether or not induction was completed. Stepwise Cox regression? was used to identify which influenced the length of time required to achieve induction of anaesthesia. For those patients whose inductions were complete, Pearson correlation coefficients were calculated to correlate induction time with dosage, total protein, and serum albumin.

\section{RESULTS}

Induction of anaesthesia was complete in three, five, and ten patients of Groups 1,2 and 3, respectively. Table I shows the total protein and serum albumin concentrations, induction dose, and induction time of all patients. Stepwise logistic regression demonstrated that dose was the only significant $(p<0.001)$ factor in determining whether induction was completed or not, and stepwise Cox regression revealed that only 
REVES, et $a$ l: : MIDAZOLAM ANAESTHESIA INDUCTION TIMES

TABLE I

Dose of Midazolam, Induction Time, Serum Protein and albumin

\begin{tabular}{|c|c|c|c|c|c|}
\hline $\begin{array}{l}\text { Patient } \\
\text { No. }\end{array}$ & $\begin{array}{c}\text { Dose } \\
\left(\mathrm{mg} \cdot \mathrm{kg}^{-1}\right)\end{array}$ & $\begin{array}{l}\text { Induction } \\
\text { complete }\end{array}$ & $\begin{array}{l}\text { Time } \\
(\mathrm{sec})\end{array}$ & $\begin{array}{l}\text { Serum } \\
\text { protein } \\
(\mathrm{gm} / \mathrm{dl})\end{array}$ & $\begin{array}{l}\text { Serum } \\
\text { albumin } \\
(\mathrm{gm} / \mathrm{dl})\end{array}$ \\
\hline 1 & 0.10 & yes & 130 & 6.7 & 4.11 \\
\hline 2 & 0.15 & yes & 180 & 7.9 & 4.41 \\
\hline 3 & 0.15 & yes & 70 & 6.7 & 3.39 \\
\hline 4 & 0.20 & yes & 110 & 7.7 & 3.91 \\
\hline 5 & 0.15 & no & - & 7.8 & 4.88 \\
\hline 6 & 0.20 & yes & 65 & 7.1 & 4.06 \\
\hline 7 & 0.20 & yes & 55 & 7.1 & 3.88 \\
\hline 8 & 0.15 & yes & 90 & 8.0 & 3.45 \\
\hline 9 & 0.15 & yes & 105 & 7.9 & 4.23 \\
\hline 10 & 0.15 & yes & 90 & 6.2 & 3.35 \\
\hline 11 & 0.15 & no & - & 6.7 & 3.56 \\
\hline 12 & 0.15 & no & - & 7.6 & 4.42 \\
\hline 13 & 0.15 & no & - & 6.8 & 3.38 \\
\hline 14 & 0.15 & no & - & 8.6 & 4.26 \\
\hline 15 & 0.10 & yes & 120 & 8.0 & 4.45 \\
\hline 16 & 0.10 & no & - & 7.3 & 4.47 \\
\hline 17 & 0.10 & no & - & 7.9 & 4.02 \\
\hline 18 & 0.10 & yes & 150 & 7.4 & 4.60 \\
\hline 19 & 0.10 & no & - & 5.9 & 3.38 \\
\hline 20 & 0.10 & no & - & 6.0 & 3.72 \\
\hline 21 & 0.10 & no & - & 6.7 & 4.73 \\
\hline 22 & 0.10 & no & - & 8.5 & 3.79 \\
\hline 23 & 0.20 & yes & 90 & 8.5 & 4.12 \\
\hline 24 & 0.20 & yes & 110 & 7.3 & 4.06 \\
\hline 25 & 0.20 & yes & 65 & 7.8 & 4.32 \\
\hline 26 & 0.20 & yes & 54 & 7.8 & 4.23 \\
\hline 27 & 0.20 & yes & 45 & 7.3 & 3.30 \\
\hline 28 & 0.20 & yes & 90 & 7.4 & 4. 16 \\
\hline 29 & 0.20 & yes & 120 & 6.2 & 4.03 \\
\hline 30 & 0.10 & no & - & 7.4 & 3.84 \\
\hline
\end{tabular}

TABLE II

albumin Concentrations* for Given Doses of Midazolam

\begin{tabular}{lccc}
\hline \hline Dose $\left(\mathrm{mg} \cdot \mathrm{kg}^{-1}\right)$ & 0.1 & 0.15 & 0.20 \\
\hline Complete Induction & $4.39 \pm 0.14(3)$ & $3.77 \pm 0.23(5)$ & $4.01 \pm 0.09(10)$ \\
Incomplete Induction & $3.99 \pm 0.18(7)$ & $4.1 \pm 0.28(5)$ & no patients \\
\hline
\end{tabular}

*Mean \pm SEM (number of patients).

the dose was significantly associated with length of time for induction. Table II shows the mean albumin concentrations at each of the three doses of midazolam for patients in whom anaesthesia was and was not induced. At any given dose of midazolam, there is no significant difference in the mean serum albumin concentration of patients who go to sleep and those who do not. Table III shows Pearson correlation coefficients for the patients in whom anaesthesia was induced $(\mathrm{n}=18)$. There is a poor correlation $(0.062, \mathrm{p}=$ 0.81 ) between total serum protein and induction time and a positive correlation $(0.524, p=0.026)$ between serum albumin and induction time (Figure 1). The strongest correlation is with dose.
There is a highly significant $(\mathrm{p}=0.003)$ negative correlation $(-0.579)$ between dose and induction time.

TABLE III

Pearson Correlation Coefficients for Induction Time Versus Midazolam Dose, Total Serum PROTEIN AND Albumin

\begin{tabular}{cccc}
\hline & $\begin{array}{c}\text { Total } \\
\text { protein }\end{array}$ & $\begin{array}{c}\text { Serum } \\
\text { albumin }\end{array}$ & Dose \\
\hline Induction time $\mathrm{r}$ & 0.062 & 0.524 & -0.579 \\
$\mathrm{p}$ & 0.807 & 0.026 & 0.003 \\
$\mathrm{n}$ & 18 & 18 & 18 \\
\hline
\end{tabular}

Where $r=$ coefficient, $p=$ probability value, $n=$ number of observations. 
TABLE IV

Mean Induction Time and Variance for Three INTRaVenous ANaEsthetic Agents

\begin{tabular}{|c|c|c|c|c|}
\hline & \multicolumn{2}{|c|}{ Premedicated } & \multicolumn{2}{|c|}{ Unpremedicated } \\
\hline & $\begin{array}{l}\text { Thiopentone } \\
\left(3 \mathrm{mg} \cdot \mathbf{k g}^{-1}\right)\end{array}$ & $\begin{array}{c}\text { Midazolam } \\
\left(0.2 \mathrm{mg} \cdot \mathrm{kg}^{-1}\right)\end{array}$ & $\begin{array}{c}\text { Diazepam } \\
\left(0.3 \mathrm{mg} \cdot \mathrm{kg}^{-1}\right)\end{array}$ & $\begin{array}{l}\text { Midazolam } \\
\left(0.2 \mathrm{mg} \cdot \mathrm{kg}^{-1}\right)\end{array}$ \\
\hline Mean induction time (sec) & 45 & 73 & 94 & 80 \\
\hline S.E.M. & 4.7 & 8.9 & 26.4 & 8.6 \\
\hline Sample variance & 530 & 1901 & 6970 & 740 \\
\hline $\mathrm{n}$ & 26 & 24 & 10 & 10 \\
\hline
\end{tabular}

S.E.M. = standard error of mean, $n=$ number of patients.

Premedicated patients received morphine $0.1 \mathrm{mg} / \mathrm{kg}$ and atropine $0.006 \mathrm{mg} / \mathrm{kg} \mathrm{IM}$.

Data from references 2 and 3.

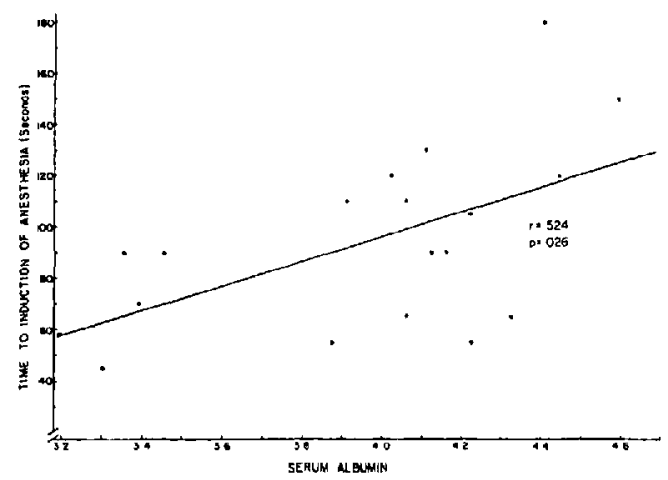

Figure 1 Plot of serum albumin concentration $(\mathrm{gm} / \mathrm{dl})$ versus time required for anaesthesia induction. Where $\mathrm{r}=$ Pearson correlation coefficient and $\mathrm{p}=$ probability value.

\section{Discussion}

Individual variation among patients to intravenous induction of anaesthesia with benzodiazepines is a clinically recognized phenomenon. ${ }^{3.5}$ To examine the reasons for the reported degree of patient variability, the variances of mean induction times from previous investigations were compared (Table IV). Sample variance is a measure of variation of individual response (induction time) to a given dose. The data come from two different studies, one in which the patients were not premedicated ${ }^{2}$ and the other in which morphine $0.1 \mathrm{mg} \cdot \mathrm{kg}^{-1}$ and atropine $0.006 \mathrm{mg} \cdot \mathrm{kg}^{-1}$ were given. ${ }^{3}$ In unpremedicated patients, sample variance of diazepam 0.3 $\mathrm{mg} \cdot \mathrm{kg}^{-1}$ greatly exceeds midazolam 0.2 $\mathrm{mg} \cdot \mathrm{kg}^{-1}$, signifying greater individual variation among diazepam than midazolam patients. The increased variance in the patients who received diazepam may be explained in part by the unequal doses administered rather than by drug differences alone, since the $E D_{95}$ for diazepam is $0.5 \mathrm{mg} \cdot \mathrm{kg}^{-18}$ while that for midazolam is 0.2 $\mathrm{mg} \cdot \mathrm{kg}^{-1} .^{9}$ In premedicated patients, thiopentone has less sample variance than midazolam, which is indicative of less individual variation in anaesthesia induction time. This supports the contention that benzodiazepines present greater individual variation than barbiturates. ${ }^{s}$

The mechanism of induction of anaesthesia is still not completely understood, but recent pharmacokinetic and pharmacodynamic reviews have enumerated some of the important considerations. ${ }^{10-13}$ Pharmacological characteristics of particular importance are lipid solubility, ionization and protein binding. Midazolam is water soluble in its vehicle at $\mathrm{pH} 3.5$, but highly lipid soluble at the physiological $\mathrm{pH}$ of $7.4{ }^{*}$ The pronounced lipid solubility in vivo undoubtedly contributes to the rapid onset of anaesthesia. Also, the pKa of midazolam is $6.1 ; i^{14}$ a relatively high proportion of the drug is not ionized at the physiological $\mathrm{pH}$ and is therefore available to cross the blood-brain barrier. However, over 95 per cent of midazolam has been shown by equilibrium dialysis to be protein bound, ${ }^{5}$ indicating that only about five per cent of an injected dose is free to cross the blood-brain barrier to produce sleep. It is certainly possible that changes in protein binding might account for individual responses to a given dose of midazolam for induction. If less drug is bound to serum protein. then more drug will be available to cross the blood-brain barrier and time for induction should be shortened.

Although protein binding data are not available, we have tested Dundee's hypothesis indirectly by examining the correlation of time for induction of anaesthesia with total serum protein concentration and with serum albumin. There is a

${ }^{*}$ From Investigational Drug Brochure, Midazolam (RO 21-3981), June 1980, Hoffman-La Roche Inc., Nutley, New Jersey. 
poor correlation between induction time and total serum protein $(r=0.062)$, which suggests that total protein concentration is unrelated to induction with midazolam. However, the weak ( $r=$ 0.524 ) but statistically significant ( $p=0.026$ ) correlation between induction time and serum albumin indicates that the higher the albumin, the more prolonged the induction time. Since most drugs are bound to the albumin fraction of serum protein, this correlation between induction time and serum albumin concentration supports a principle of pharmacokinetics and pharmacodynamics: induction time will be prolonged when less drug is available to the brain because of more extensive albumin binding. ${ }^{11,12}$ The effect of protein binding would be expected to be most pronounced when drug levels are highest, ${ }^{15}$ that is, during induction of anaesthesia. This is because the amount of free drug is greatest at that time. During steady state anaesthesia the effect of protein binding is far more complex, and such factors as tissue binding must be considered. ${ }^{16}$ Emergence from anaesthesia will depend to a large extent on such factors as receptor and tissue binding as well as pharmacokinetic variables (drug clearance and elimination half-life).

Because protein binding studies were not done, we cannot conclude from the present data that individual variation in anaesthesia induction time is dependent on each patient's protein binding of midazolam. The time to induction is, however, clearly influenced by dose. The highly significant $(\mathrm{p}=0.003)$ negative correlation between dose and induction time $(r=-0.579)$ indicates that the greater the induction dose, the shorter the induction time. Thus administration of the appropriate dose of a drug appears to exert a more significant effect on the induction time than does the serum albumin concentration. This is not surprising, since dose is empirically known to be the single most important determinant of rapidity and reliability of anaesthesia induction.

In conclusion, it appears that the individual variation in induction time noted with the use of midazolam for induction of anaesthesia may be affected by the degree of protein binding of the drug. This influence is less significant than administration of the appropriate dose of the drug.

\section{ACKNOWLEDGEMENTS}

The authors wish to thank Dr. Igor Kissin for his constructive criticism of this work and Rosemary Craighead for her invaluable assistance in the preparation of the manuscript.

\section{REFERENCES}

1. Fragen, R.J., Gahl, F. \& Cald dwell, N. A water soluble benzodiazepine. Ro 21-3981, for induction of anesthesia. Anesthesiology 49: 41-43 (1978).

2. Reves, J.G., Corssen, G. \& Holcomb, C. Comparison of two benzodiazepines for anaesthesia induction: midazolam and diazepam. Can. Anaesth. Soc. J. 25: 211-214 (1978).

3. Reves, J.G., Vinik, R., Hirschfield, A.M. \& HolcomB, C. Midazolam compared with thiopentone as a hypnotic component in balanced anaesthesia: a randomized, double-blind study. Can. Anaesth. Soc. J. 26: 42-49 (1979).

4. Conner, J.T., Katz, R.L., Pagano, R.R. \& Graham, C.W. RO 21-3981 for intravenous surgical premedication and induction of anesthesia. Anesth. Analg. 57: 1-5 (1978).

5. DundeE, J.W. New I.V. anaesthetics. Br. J. Anaesth. 5I: 641-648 (1979).

6. Halperin, M., Blackwelder, W.C. \& Verter, J.I. Estimation of the multivariable logistic risk function: a comparison of the discriminant function and maximum liklihood approaches. J. Chronic. Dis. 24 : $125-158$ (1971)

7. Cox, D.R. Regression models and life tables (with discussion). J. Roy. Statist. Soc. B. 34: 187-220 (1971).

8. Stella, L., Torri, G. \& Castiglioni, C.L. The relative potencies of thiopentone, ketamine, propanidid, alphaxalone and diazepam. A statistical study in man. Br. J. Anaesth. 51: 119-122 (1979).

9. Reves, J.G., Kissin, I. \& Smith, L.R. The effective dose of midazolam. Anesthesiology 55: 82 (1981)

10. Gibaldi, M. \& Perrier, D. Pharmacokinetics. 1st ed. New York: Marcel Dekker, Inc. (1975).

11. Hug, C.C. Pharmacokinetics of drugs administered intravenously. Anesth. Analg. 57: 704-723 (1978).

12. Hull, C.J. Pharmacokinetics and pharmacodynamics. Br. J. Anaesth. 51: 579-594 (1979).

13. Norman, J. Drug-receptor reactions. Br. J. Anaesth. 5l: 595-601 (1979)

14. Pugliski, C.V. Personal communication.

15. LEVY, G. Effect of plasma protein binding of drugs on duration and intensity of pharmacological activity. Letter to the editor. J. Pharm. Sci. 65: 1264-1265 (1976).

16. McNamara, P.J., LeVy, G. \& Gibaldi, M. Effect of plasma protein and tissue binding on the time course of drug concentration in plasma. J. Pharmacokinet Biopharm. 7: 195-206 (1979).

\section{RÉSUMÉ}

On observe des variations individuelles dans la vitesse d'induction avec les anesthésiques intraveineux.

Il y a moins d'agent actif libre disponible pour traverser la barrière hémo-encéphalique dans 
le cas des anesthésiques à haute affinité (liaison) protéique. Comme cela peut prolonger le temps d'induction, nous avons établi des corrélations entre les vitesses d'induction, les concentrations sériques d'albumine, les protéines totales. et diverses doses de Midazolam, un anesthésique à haute affinité protéique.

Nous avons trouvé une mauvaise corrélation $(r=0,063)$ entre la vitesse d'induction de cet agent et les taux sériques de protéines, une corrélation faible $(r=0,524)$ mais statistiquement significative $(p=0.026)$ entre la vitesse d'induction et le taux d'albumine sérique et, enfin, une corrélation négative $(r=-0,579)$ hautement significative $(p=0,003)$ entre la dose d'agent administrée et la vitesse d'induction.

L'administration d'une dose adéquate de Midazolam semble donc influencer la vitesse d'induction plus que la concentration sérique d'albumine. 